Finance and Economics Discussion Series Divisions of Research \& Statistics and Monetary Affairs Federal Reserve Board, Washington, D.C.

\title{
Consumers' Use of Debit Cards: Patterns, Preferences, and Price Response
}

\section{Ron Borzekowski, Elizabeth K. Kiser, and Shaista Ahmed 2006-16}

NOTE: Staff working papers in the Finance and Economics Discussion Series (FEDS) are preliminary materials circulated to stimulate discussion and critical comment. The analysis and conclusions set forth are those of the authors and do not indicate concurrence by other members of the research staff or the Board of Governors. References in publications to the Finance and Economics Discussion Series (other than acknowledgement) should be cleared with the author(s) to protect the tentative character of these papers. 


\title{
Consumers' Use of Debit Cards: Patterns, Preferences and Price Response
}

\author{
Ron Borzekowski* \\ Elizabeth K. Kiser ${ }^{\dagger}$ \\ Shaista Ahmed $\ddagger$
}

April 2006

\begin{abstract}
Debit card use at the point of sale has grown dramatically in recent years in the U.S., and now exceeds the number of credit card transactions. However, many questions remain regarding patterns of debit card use, consumer preferences when using debit, and how consumers might respond to explicit pricing of card transactions. Using a new nationally representative consumer survey, this paper describes the current use of debit cards by U.S. consumers, including how demographics affect use. In addition, consumers' stated reasons for using debit cards are used to analyze how consumers substitute between debit and other payment instruments. We also examine the relationship between household financial conditions and payment choice. Finally, we use a key variable on bank-imposed transaction fees to analyze price sensitivity of card use, and find a 12 percent decline in overall use in reaction to a mean 1.8 percent fee charged on certain debit card transactions; we believe this represents the first microeconomic evidence in the U.S. on price sensitivity for a card payment at the point of sale.
\end{abstract}

\footnotetext{
*Federal Reserve Board, 20th and C St., NW, Washington, DC 20551, ron.borzekowski@frb.gov

${ }^{\dagger}$ Federal Reserve Board, 20th and C St., NW, Washington, DC 20551, elizabeth.k.kiser@frb.gov

${ }^{\ddagger}$ Woodrow Wilson School of Public and International Affairs, Princeton University. The views expressed herein are those of the authors and do not necessarily reflect those of the Board of Governors or the staff of the Federal Reserve System. The authors thank Elise Tosun and David Kite for excellent research assistance.
} 


\section{Introduction}

Annual debit card transactions at the point of sale have been growing at over twenty percent per year since 1996 and now exceed credit card transactions 11 In sharp contrast, the volume of checks has decreased dramatically since the mid-1990's and is currently falling at three to five percent per year 2 The trends in ATM cash withdrawals and credit card transactions are both flat or growing only slightly. As a result, debit is becoming the dominant form of payment for many consumers.

This shift raises important questions for both public policy and corporate strategy; however, little information is available on patterns of debit card use or the preferences and motivations of consumers adopting this technology. From a macroeconomic perspective, the extent to which debit card transactions substitute for cash and checks has a direct impact on money demand and the efficiency and overall social cost of the payment system. The rapid growth and innovation in this area has also raised microeconomic concerns regarding industry structure and organization, as well as the appropriate role of regulatory and antitrust policy. Recent years have witnessed substantial government and private litigation over payment card associations' network governance and the rules surrounding fee setting and card acceptance 3

Questions about consumers' use of debit cards and other payments are made more intriguing by the fact that payment instruments are seldom priced explicitly: Although merchant cost and card issuer revenue may vary dramatically with the method of payment, this fact is generally unknown to the consumer. Charging consumers more for using a given payment method ("surcharging"), is not currently practiced in the U.S.; however, it is a key component of several proposals to reform the payment system in the U.S. and abroad. Our results on consumer price response are highly relevant for this debate.

This paper examines these questions using a nationally representative sample of consumers from

\footnotetext{
${ }^{1}$ Source: Authors' calculations from the 2006 EFT Data Book; ATM and Debit News (2005).

${ }^{2}$ See Gerdes, Walton II, Liu and Parke (2005).

${ }^{3}$ These actions include the U.S. Department of Justice's challenge of governance practices at Visa and MasterCard, and the civil suit led by Wal-Mart against the card associations' rules on credit and debit card acceptance. More recently, the pricing of interchange - interbank payments made when credit or debit cards are used - has stirred debate in the U.S. and abroad. In 2003, the Reserve Bank of Australia (RBA) mandated substantial reductions in some interchanges fees, along with other changes; the EU's Competition Commission continues to scrutinize interchange fees; in the UK, the Office of Fair Trading (OFT) has established in separate decisions in 2005 that Visa and MasterCard engaged in anticompetitive practices and is pursuing further action against them.
} 
midyear 2004. We begin by describing the current state of debit card holding and use in the U.S. and how each varies with household demographic characteristics. We then examine the motivations for using debit, how consumers substitute between debit and other payment methods, and what underlying needs debit satisfies in consumer utility, including the extent to which debit cards serve as a method of behavioral restraint. These issues are addressed using responses to open-ended questions from the survey.

Finally, we estimate a series of probits to investigate how demographics and financial conditions relate to debit card use and, most importantly, how consumers respond to fees assessed by banks on debit card transactions. It is here that we investigate how consumers' choice of payment instrument responds to price. As mentioned, the vast majority of consumers face no price variation at the point of sale. A notable exception, however, are customers of the minority of banks who charge debit cardholders for certain types of transactions at the point of sale. Using our survey's information on these fees, we are able to provide what we believe to be the first microeconomic evidence on the price sensitivity of consumers to fees on a specific payment method at the point of sale.

Our results indicate that the likelihood of using a debit card decreases monotonically with age, and is higher for women than for men, but does not vary substantially with income. The frequency of use varies with age, family structure, and income, but not gender. We also find that household financial conditions and expectations affect debit card use: Households who have recently experienced bad financial outcomes are more likely to substitute credit for debit, while consumers with negative expectations about the future are more likely to use debit rather than credit. These findings suggest that consumers may have an underlying preference for spending from liquidity, and that credit cards serve as a source of liquidity following adverse financial events.

Debit cards appear to serve primarily as a substitute for cash and checks, and contrary to some popular wisdom (but consistent with other empirical evidence), only a small share of debit card holders (5.8 percent) explicitly report using debit as a method of behavioral restraint.

Finally, we find a substantial price response. Consumers respond strongly to fees charged for so-called PIN debit transactions by using a signature rather than a PIN to secure transactions; however, the fee also reduces the likelihood that the consumer uses a debit card at all. On average, a 
1.8 percent fee on a debit card transaction (nearly all of which are charged only on PIN transactions) is associated with a 12 percent decline in the likelihood of use. We believe this to be a conservative estimate of price response at the point of sale. This estimate suggests that surcharging of payment methods would likely cause a sharp decrease in use of the surcharged instrument.

\section{Background}

\section{$2.1 \quad$ Literature}

Several prior studies of U.S. consumers have investigated demographic patterns in the adoption of payment methods. Using various versions of the Survey of Consumer Finances (SCF), Kennickell and Kwast (1997) (1995 SCF), Stavins (2001) (1998 SCF) and Zinman (2005) (2001 SCF) find similar results: Newer technologies such as electronic banking and bill payment or debit cards are used most frequently by younger, better-educated individuals $4_{4}^{4}$ Income appears to be non-linearly related to debit card use in these studies, with the probability of use rising with income at first and then declining among the wealthiest households. Klee (2005) summarizes and extends many of these results by examining several years of the SCF. Three additional studies using proprietary datasets mirror these results: Carow and Staten (1999) specifically examine debit card use early in its diffusion, while Rysman (2004) focuses on the role of demographics in consumers' choice of credit card brands; Hayashi and Klee (2003) examine consumer adoption of debit cards as well as direct deposit and electronic bill payment.

Several other papers examine consumers' motivations when choosing among payment methods. Working from the empirical results in Kennickell and Kwast (1997), survey data and focus groups, Mantel (2000) offers a framework to analyze payment choice. Hirschman (1982) uses a very similar approach in her earlier research identifying eleven attributes that consumers value when choosing how to pay. In contrast to these more qualitative approaches - neither of which directly address the substitution between differing options for payment - Zinman (2005) focuses specifically on

\footnotetext{
${ }^{4}$ Also, Jonker (2005) and Loix, Pepermans and Van Hove (2005) analyze payment method adoption in the Netherlands and Belgium, respectively. A survey of earlier work on payment choice can be found in Hancock and Humphrey (1998).
} 
the consumer choice to use debit cards versus other payment instruments. Using the $2001 \mathrm{SCF}$, he considers whether consumers use debit cards as a method of behavioral restraint, and finds evidence that the majority of debit card users appear to have pecuniary rather than behavioral motives for their choice of payment; using different methods, our findings corroborate his.

Evidence on consumer response to differential pricing of payment methods is extremely scarce. Using aggregate data from Norway from 1989 through 1995, Humphrey, Kim and Vale (2001) estimate own- and cross-price elasticities for ATM cash withdrawals, checks and debit. They find own-price elasticities for each payment method ranging between -0.3 and -1.1 . To our knowledge, Amromin, Jankowski and Porter (2005) provide the only prior microeconomic evidence on consumers' price response to payment method in the U.S.; they find a strong consumer response to asymmetric pricing of cash and electronic toll payments on the Illinois Tollway.

\subsection{The Debit Card Industry}

As with a credit card, a consumer uses a debit card by presenting the card to a retail merchant. The merchant initiates the transaction message, which travels over a debit network to the bank that issued card or its processor, which in turn checks a record of the cardholder's deposit account 5 The issuing bank sends an authorization message back to the merchant. The transaction proceeds and the purchase amount is debited from the cardholder's deposit account in real time or with a slight delay, depending on the specifics of the transaction.

There are two types of point-of-sale debit transactions: those authorized by a personal identification number (PIN) and those authorized by a signature. With a PIN debit transaction, the customer must have a network-branded debit card, and the merchant must have a debit terminal compatible with the network displayed on the card $\sqrt[6]{6}$ The customer swipes the card in the terminal and enters a personal identification number (PIN). The transaction runs over the debit network, and the customer's deposit account is debited immediately.

With a signature debit transaction, the customer has a Visa- or MasterCard-branded debit card, likewise linked to a deposit account, and the merchant need only have access to the Visa

\footnotetext{
${ }^{5}$ An exception is a stored-value card, for which the cardholder has no deposit account.

${ }^{6}$ One exception is a "PIN-less" Internet transaction, for which the merchant needs no terminal.
} 
or MasterCard credit card networks; the merchant may, but need not, have a debit card terminal. Instead of keying in a PIN, the customer secures the transaction with a signature 7 The transaction runs over the credit card network and then to the customer's bank; the customer's account is debited after a short delay (usually within 2 days).

An interchange fee is the fee that a merchant's bank pays to the consumer's bank for a debit card transaction. The interchange fee is passed on to the merchant via the merchant discount, which is the fee the merchant pays its bank for carrying the transaction to the network. At the time of this study, interchange fees are higher for signature debit transactions than for PIN debit transactions. As a result, merchants prefer less costly PIN-based debit transactions, while card-issuing banks prefer the higher-revenue signature transactions.

As a result of these opposing incentives, some banks charge fees to their customers for conducting PIN-based debit transactions. Using a separate bank-level survey, we estimate that as of mid-2004, approximately 15 percent of banks nationwide charged fees for using PIN-based debit 8 The median PIN debit per-transaction fee among banks charging the fee is 75 cents.9.$^{9}$ We analyze the consumer response to PIN debit fees using consumer survey data in section 5. Because merchants are currently constrained from most surcharging of this type, we can use the findings on bank-imposed fees to infer what might occur if merchant surcharging were allowed and implemented.

\section{Consumer Use of Debit Cards}

\subsection{Survey Data}

The data used in the analysis below were collected during March, April, and May 2004 as a special module of the Michigan Surveys of Consumers; this set of questions was included in order to gather information about consumers' experience with debit cards. Consumers were asked whether they use debit cards to make purchases, how often they do so, and the reasons behind these decisions,

\footnotetext{
${ }^{7}$ Increasingly, no signature is required for small-value transactions at certain merchants (for example, at major fast-food chains).

${ }^{8}$ The depository institution survey was conducted by Moebs Services, Inc., during June, 2004, on a stratified random sample of 800 banks and thrifts.

${ }^{9}$ The survey also indicated that fewer than one percent of banks reported charging fees for signature debit.
} 
along with several questions about any fees their banks may charge for using a debit card. The questions on reasons for using or not using debit were asked as open-ended questions, allowing us to categorize them several ways for analysis. The final dataset is a nationally representative sample of 1,501 distinct households. The representative nature of the sample is an improvement over the most recent industry studies that detail U.S. debit card use ${ }^{10}$

\subsection{Descriptive Statistics of Debit Card Use}

Table 1 shows the composition of our sample. Eighty-eight percent of households reported having a checking account or a similar transaction account at a depository institution; this is consistent with the $2001 \mathrm{SCF}$, another comparable nationally representative data source ${ }^{11}$ About 52 percent of households (60 percent of households with a checking account) have a debit card; thus, a large margin still remains for growth in cardholding. Approximately 45 percent of households (86 percent of households with a debit card) reported having used the card to purchase items at stores in the twelve months preceding the survey.

The numbers on debit card use in our survey are also consistent with results obtained in the 2001 SCF. In the 2001 SCF, 44 percent of households with a checking or savings account reported using a debit card to make purchases; in our survey, 52 percent of such households reported doing so (consistent with the growth in debit card use since 2001). Our debit card ownership rate is below that reported in the 2004/2005 ABA/Dove Study, which reports 83 percent of consumers possessing a card; this difference is likely due to ABA/Dove's more affluent sample. Notably, our card usage rate conditional on holding a card exactly matches the 87 percent reported by ABA/Dove.

\subsection{Demographic Variation in Debit Card Use}

Table 2 shows a breakdown of debit card use by demographic group. The left column shows the proportion of debit card holders in each demographic category who use their debit cards at least

\footnotetext{
${ }^{10}$ For example, the 2004 ABA/Dove study sample consists of checking account holders who voluntarily responded to a written survey, with a response rate of about 7 percent; see Dove Consulting and the American Bankers Association (2005). The Michigan Survey sampling frame, in contrast, includes all U.S. households regardless of account holdings and has a considerably higher response rate (around 70 percent).

${ }^{11}$ Eighty-nine percent of households in the 2001 SCF reported holding a checking account at some type of depository institution; the SCF definition of a checking account is slightly broader than the Michigan Survey's.
} 
occasionally; the right column shows debit card usage rates among all households with a checking account. The difference between these two groups is the set of checking account holders who report not having a debit card, and therefore are unable to use one.

Overall differences in debit card use are driven by debit card holdings. To see this, note the difference in usage rates between debit card holders and checking account holders: High debit card use is reported among all demographic groups of debit card holders. In contrast, debit use varies to a much greater extent within the broader population of households with a checking account. We return to analyzing debit card holding shortly.

For the descriptive statistics, we focus on the rates among checking account holders (rather than debit cardholders) because they more closely represent the customer base of U.S. retail outlets. Debit card use varies substantially with several demographic variables. As expected, age is a strong predictor of debit card use: Among checking account holders, the probability of using a debit card is decreasing monotonically with age. This finding is consistent with other studies on debit card use (ABA/Dove) as well as the other studies of electronic payment methods cited earlier. We are unable to determine from cross-sectional data whether this relationship represents an age effect or a cohort effect; that is, we cannot say whether younger U.S. consumers will "age out" of debit card use or whether debit card use will increase over time as younger, debit-preferring cohorts age. On the one hand, once a consumer has "adopted" debit card technology, he or she may use it indefinitely. On the other hand, if age is positively correlated with credit access, those with a preference for credit cards are less likely to use debit, so some younger consumers may indeed eventually age out of debit cards as they establish credit histories.

Education is, as expected, predictive of debit card use among checking account holders. About 38 percent of respondents with a high school diploma or less report using debit cards. The highest usage rates, around 60 percent, are among individuals with some college or a college degree; those with a graduate degree are slightly less likely to use debit cards. The low usage rate among less educated households likely reflects lower account holdings and potentially a lesser familiarity with electronic payment technology, consistent with the prior literature. The slightly lower rate among the highly educated is likely correlated with age (and the associated technological cohort effect) 
and/or access to credit cards, consistent with Zinman (2005).

With the exception of lower card use for the lowest income category (with a corresponding lower rate of checking account holdings), income is not a strong predictor of debit card use. This finding is unsurprising given the potential substitutes for debit cards: Although higher income households are generally more likely to use electronic technologies, higher income households have better access to credit cards, an important substitute for debit cards. Also, because income is positively correlated with age, the higher income categories also reflect older households. Homeowners are less likely than renters to use debit cards, again probably due to the high correlation between homeownership and access to credit. These compositional effects are controlled for in the probit analysis.

Women in the sample have a higher probability of using debit cards: Conditional on holding a card, 90 percent of women use the card, compared with 81 percent of men. Among all checking account holders, 55 percent of women use debit cards, compared with 47 percent of men. Black and Hispanic households have higher rates of debit use than respondents of other ethnicities. Single respondents are more likely than married respondents to use debit cards, and households with children present are considerably more likely than those without children to use debit cards.

\subsection{Consumer Substitution Patterns and Payment Choice Drivers}

The structure of our survey gives us a unique opportunity to investigate the payment methods for which debit serves as a substitute, as well as the needs in consumer utility that debit satisfies. To explore these areas we use the set of open-ended questions on the reasons underlying the choice between debit and other payment options. Two questions were asked in this open-ended fashion: Respondents who reported using debit were asked why they use debit cards, and households who reported that they have a card but do not use debit were asked why not. ${ }^{12}$

For each respondent, we used keywords to construct two sets of additional variables. First, we constructed three dummy variables for alternatives to debit: cash, check and credit. Each

\footnotetext{
${ }^{12}$ The exact text of the questions is as follows. Households who use debit were asked, "We are interested in understanding the reasons why people use debit cards to make purchases. Why do you use your debit card to make purchases? Any other reasons?" Those who reported not using debit were asked, "We are interested in understanding why people don't use debit cards to make purchases. Why don't you use your debit card to make purchases? Any other reason?"
} 
dummy takes on a value of 1 if the respondent mentioned that alternative payment method in their response. These variables are not mutually exclusive; more than one payment substitute could be coded. Both the first and second (if present) reported reasons were used to code these indicators.

The other set of dummy variables references what we call "payment choice drivers," or the underlying needs that are satisfied by consumers' chosen payment methods. Using keywords, we construct seven dummies that refer to consumer desires for specific features: Time (a preference for speed at, e.g., the checkout counter), Convenience, Money (a pecuniary motive such as avoiding interest payments or fees, using the float, or seeking airline miles or cash rewards points), Restraint (a desire to limit overspending), Tracking (ability to track and record purchases), Acceptance (acceptance of the payment method by retailers), and Other (not otherwise classifiable). This partition of the data allows us to investigate the primitives of payment choice, as each payment method may satisfy multiple consumer desires to a greater or lesser degree.

Descriptive statistics on the "substitute" dummy variables are shown in table 3 for debit users and non-users, conditional on having a debit card. The left column shows the share of debit users who use debit instead of the respective alternative payment type. Nearly half (48.5 percent) of debit users mention that debit serves as a substitute for cash. About 32 percent of debit users report using debit instead of checks, and 19 percent say debit serves as a substitute for credit cards. About 21 percent report no specific alternative payment method. These numbers show that debit card users view debit cards primarily as a substitute for "paper" payment methods.

The right column of table 3 shows the share of debit non-users who report using the respective payment type instead of debit. Fifty-five percent refer to credit cards as preferable to debit; 31 percent refer to checks and 23 percent refer to cash. Twenty-three percent of debit non-users mention no alternative payment method. Thus, the majority of debit non-users prefer credit cards to debit cards.

The payment choice drivers for debit users and non-users are shown in table 4 These drivers vary substantially between debit users (left column) and non-users (right column). A remarkable 88 percent of debit users report that they use debit for its convenience relative to other payment methods. Debit users also referenced Time, Money, Tracking, Restraint, Acceptance, and other 
reasons, in descending order. In contrast, debit card non-users referred most frequently to Tracking (40 percent) or to various other needs (36 percent), relative to debit. Pecuniary motives were also popular at 21 percent (many of these referenced credit card rewards programs). The other categories were mentioned by fewer than 10 percent of respondents.

To investigate how these payment choice drivers enter into the available payment methods, we compute means of the substitute dummies by payment choice driver for debit card users (table 5). A few numbers are noteworthy. Respondents reporting a desire for Time and Convenience view debit as a substitute for cash and, somewhat less strongly, for checks. Consumers with pecuniary motives substitute debit for checks, followed by cash and credit (several respondents reported a desire not to buy the checks themselves) ${ }^{13}$

About 61 percent of respondents who cite payment method acceptance as a reason for preferring debit (5 percent of all debit card users) indicated they substitute debit for credit. This is consistent with certain large retailers' (e.g., Costco's) non-acceptance of certain credit cards. ${ }^{14}$

\subsection{Debit Cards as a Method of Behavioral Restraint}

Because debit cards draw from liquidity and credit cards draw from debt, payment choice is potentially intertwined with household consumption decisions. The behavioralist approach to modeling economic behavior, as in Thaler (1985) and Prelec and Loewenstein (1998), raises the possibility that consumers with limited commitment power may choose to precommit to lower consumption by paying out of liquidity rather than debt. Zinman (2005) uses information on revolving credit card balances and other variables in the SCF to infer whether consumers appear to use debit cards as a means of behavioral restraint; he finds support instead for pecuniary motives for payment choice.

The Restraint category included above in the reasons for using debit is of particular use in evaluating how consumers substitute between debit cards and credit cards. Notably, consumers

\footnotetext{
${ }^{13}$ We explore how the observable characteristics of each payment method (as opposed to self-reported drivers) affect substitution among payment methods in Borzekowski and Kiser (2006).

${ }^{14}$ The merchant decision not to accept credit cards is driven by the fact that interchange fees - the fees paid by merchant banks to card-issuing banks, and borne by merchants - are typically higher for credit cards than for debit cards. See, for example, Rochet and Tirole (2002), Gans and King (2003), Schwartz and Vincent (2003), Wright (2002), and Chakravorti and To (1999), and Federal Reserve Board (2004) for discussions of the role of interchange fees in merchant acceptance.
} 
citing Restraint overwhelmingly view debit as a substitute for credit. These consumers fall clearly into the "behavioralist" explanation of debit use; however, they comprise only 5.8 percent of debit card holders. This finding of only a small share of consumers who use debit as a commitment mechanism to control spending is consistent with Zinman's (2005) results.

\section{Multivariate Analysis}

\subsection{Debit Card Holding and Use}

To further examine debit card use, we estimate a series of probit regressions. The previous univariate results indicate that card holding is itself an important determinant of use. For this reason, we first predict debit card holding among checking account holders; the results are shown in the first column in table 6. The second column shows the results of a probit predicting debit card use among the same set of banked households. The third column shows results from predicting debit card use, restricting the sample to debit card holders ${ }^{15}$

The first column shows that age, education, and regional variation drive debit card holding. Debit card holding is monotonically decreasing with age. Respondents in the youngest age category (age 18 to 24 ) are predicted to be the most likely to hold a debit card, at 84 percent. This percentage drops to 51 percent in the 55-64 age category and down to 65 percent for households age 65 and older. The educational differences appear between those with no college education and those with at least some years in college. Divorced respondents are more likely to use debit, perhaps due to the increased likelihood of paying interest on revolving credit card debt. The analysis also shows regional variation, with households in the West much more likely to have a debit card.

These differences in predicted debit card holdings may result from differences in the underlying desire to use debit or from other sources. Households without debit cards may choose not to have them because they would not use them. Another explanation is that supply-side factors may affect card ownership. For example, some people may choose not to have a debit card because they have

\footnotetext{
${ }^{15}$ Another approach would be to jointly estimate the household's decisions to hold a debit card and to use it. To obtain identification in such a model would require variables that affect one decision but not the other; we have been unable to find such variables in this survey.
} 
little opportunity to use them $\sqrt{16}$ However, this is a fairly unlikely explanation today given the widespread acceptance of debit cards by merchants. More likely, some consumers may actually have these cards and not know it; in this case, marketing and education campaigns could spur use. Finally, some banks may choose not to offer their customers (or all of their customers) debit cards.

The next column shows results from the probit modeling the probability that the household uses debit cards, taken among all households with a checking account. As in the holdings regression, region, age, the divorce indicator, and education are statistically significant predictors of debit card use. Unlike the holdings regression, gender is a strong predictor of debit card use.

The age and regional results are weaker in the third column, where use is predicted only for debit card holders. This regression shows no effect of education or marital status. The region and age variables still have some predictive power; however, the coefficient on gender is still significant and is larger. Respondents in the two youngest age categories (age 18 to 34) are predicted to be the most likely to use a debit card, at 94 percent; this is consistent with the conditional means in the sample. This percentage drops slightly to 82 percent in the $55-64$ age category and to 71 percent for households age 65 and older. Thus, conditional on having a debit card, consumers across age categories are very likely to use them.

Taken together, these estimates indicate that overall, younger female adults with at least some college education are the most likely to use debit cards, as are households in the West and South. Women are no more likely to have cards, but are more likely to use them. This pattern likely stems from household division of labor and the respective shopping patterns of women and men (note that supermarkets were among the earliest merchants to accept debit cards). The regional and age differences derive both from a lower likelihood of having a card and a lower probability of use conditional on possessing a card (and both of these are likely based, at least historically, on differing regional patterns of merchant acceptance of debit cards). In contrast, well-educated respondents are more likely to report having a debit card than those without any college education, but they are no more likely to use the cards, conditional on having them.

\footnotetext{
${ }^{16}$ In the early years of debit cards, slow adoption of debit cards by consumers likely resulted from low acceptance rates of debit cards by retail merchants. Borzekowski and Kiser (2005) identify these network effects between consumer use and merchant acceptance of debit cards over the period 1985-2002.
} 


\subsection{Frequency of Debit Card Use}

Total debit card transactions in the economy depend not only on debit card holdings and the likelihood of using a card at all, but also on the intensity of card use. For debit card users, the survey included a question on the frequency of debit card purchases per week. To our knowledge this is the first representative U.S. sample to document the frequency of debit card use ${ }^{17}$ The data show that the median U.S. debit-using household performs three debit transactions per week, with a slightly skewed distribution (figure 1). Twenty-two percent of households reported seven or more debit transactions per week. Thus, although only about half of households use debit cards, many of those who do use the cards use them intensively.

The estimates from the ordered probit on the frequency of debit card use, conditional on using a debit card at all, are shown in the fourth column of table $6{ }^{18}$ Overall, age and family structure appear to have an influence on how often respondents use debit cards. The age coefficients show some similarity to those in the probit of debit card use: Households aged 65 and older use their cards less frequently than younger households. However, several differences are present between the use and frequency models. Conditional on using the card, households with incomes of $\$ 100,000$ or more use debit cards more frequently than other groups. Households with one or more children also use debit more frequently, a result that is unsurprising given the likelihood of an overall higher frequency of shopping for these households. Finally, women, while more likely to use a debit card, use it no more frequently than men, conditional on use. Northeastern households use debit less frequently than those in the other three regions.

\subsection{Consumer Expectations and Debit Card Use}

Because the Michigan Survey is also used as a key source of information on consumer confidence and economic expectations, we are able to link responses to these types of questions to debit card use. Although prior work has been done on how credit card debt factors into the consumption

\footnotetext{
${ }^{17}$ The ABA/Dove study provides some information on the frequency of card use in their sample; using numbers in their report, we calculate that the mean number of transactions for debit card users in their sample is about 5.3 transactions per week. See Dove Consulting and the American Bankers Association (2005) p. 53.

${ }^{18}$ The seven frequency bins used to construct the dependent variable are: less than once a week, once a week, twice a week, three times, four times, five times, and six or more times a week.
} 
decision, little is known about how payment choice and consumption interact 19 From this set of consumer financial condition variables, we can investigate how consumers' financial outcomes and expectations about the future may influence the decision to draw from liquidity (debit cards) versus debt (credit cards).

Table 7 shows the results from a probit predicting debit card use as a function of demographics and variables on household financial expectations. Because we focus here on substitution between liquidity and debt, the probit was performed for only those respondents who reported that they substitute between debit cards and credit cards 20 Respondents are less likely to use debit cards (i.e., more likely to use credit cards) if their financial situation is worse now than a year ago. They are more likely to use debit (and less likely to use credit) if they expect their financial situation to be worse in a year, or if they expect a high probability of job loss over the next year. This result is consistent with Sullivan's (2005) finding that some consumers use credit cards to smooth consumption during spells of unemployment.

These estimates suggest that households choose to spend from liquidity if they expect their economic situation to worsen, and choose (or have chosen) to spend from debt if their economic situation has already declined. Together, the results indicate that consumers prefer to spend from liquidity unless they are cash constrained, and use credit cards as a source of liquidity in times of financial stress. Like the descriptive finding on reasons for using debit cards, this finding does not provide direct support for commitment-based use of debit cards. Rather, it points to an inherent preference for spending from liquidity, which may have (unobserved in this sample) either pecuniary or behavioral motives.

\section{$5 \quad$ Effects of Fees on Debit Card Use}

We now expand the analysis to examine the role of bank fees in households' choices regarding debit card use. As described earlier, at the time of the survey, about 15 percent of banks charged

\footnotetext{
${ }^{19}$ For example, Gross and Souleles (2002) use credit card data to investigate the relationship between liquidity constraints and consumption.

${ }^{20}$ The subset of consumers defined as substituting between debit and credit includes both debit card users who report preferring debit to credit, and debit card non-users who report preferring credit cards to debit cards.
} 
consumers to use their debit cards for PIN-based transactions at the point of sale. The primary motivation for these fees was to encourage consumers to use signature debit instead of PIN debit. Survey respondents' reports of whether their banks charge fees for debit card transactions are used in the analysis below to measure the consumer response to these fees.

\subsection{Estimation of Price Response}

To explore consumer response to debit card transaction fees, probits were estimated that predict debit card use as a function of demographics and the presence and level of per-transaction debit card fees ${ }^{21}$ Table 8 shows the probit results among debit card holders. The effect of the fees can be seen in the first and second columns of the table. Column 1 includes a dummy variable for whether the bank charges a fee for using debit; column 2 includes the level of the fee. (The dummy variable takes on a value of 1 if the respondent reports that his or her bank charges either a PIN fee or a signature fee; however, results from our bank survey indicate that most household reports of a signature fee are likely incorrect.)

In both cases, the results indicate that the imposition of the fee significantly lowers the household's probability of using debit. Ninety percent of households whose banks do not charge a debit card fee are predicted to use their debit cards; this predicted probability drops to 79 percent among households whose bank charges a fee - about a 12 percent decline in the likelihood of use 22 This response is substantial when compared with the magnitude of the typical debit card fee and purchase amount. Because the median fee charged by depository institutions is about 75 cents, with a mean purchase amount of about $\$ 42$, the median fee represents about 1.8 percent of the purchase amount. A 12 percent decline in overall use in reaction to a 1.8 percent fee charged on only a subset of debit transactions is in our view a substantial price response. Although not directly comparable, these estimates are larger than those found by Humphrey et al. (2001) using aggregate data; their own-price elasticities range for each payment instrument range between 0.3 and -1.1.

\footnotetext{
${ }^{21}$ If consumers choose their financial institutions based upon the presence or level of these fees, then these regressors will be correlated with the probit error. However, two factors mitigate this concern: First, consumers rarely switch banks; second, when choosing an institution, branch location and branch and ATM network size are empirically the dominant factors in the consumer's choice. See, e.g., Kiser (2002).

${ }^{22}$ These predicted probabilities are evaluated at the mean values of the other regressors.
} 
Recall that the bank's incentive to charge a fee on PIN debit transactions is to "steer" customers away from PIN-secured debit and toward signature-secured debit; this is due to the higher interchange fee revenue currently received by the card-issuing bank for a signature debit transaction. Because the survey asked respondents whether they use a PIN or a signature at the point of sale, we included the type of debit transaction used as a dependent variable in the regression shown in the third column of table 8, using as a regressor an indicator for whether the respondent reports that his or her bank charges a PIN fee. ${ }^{23}$ This allows us to test whether the PIN fee serves to steer debit cardholders toward signature-secured transactions. We coded a respondent as using signature debit if he or she reports using only signature debit; i.e., never uses a PIN. The probit shows that the imposition of PIN debit fees does indeed appear to drive consumers to signature debit.

Thus, we find that PIN fees steer customers to use signature debit, but also reduce the likelihood that they use debit at all. This finding is noteworthy from the perspective of bank pricing. It is unlikely that banks setting these fees intend for consumers to stop using debit cards altogether. Presumably, a bank would rather receive a (lower-than-signature) PIN interchange fee than no interchange fee at all (and an associated higher processing cost for checks or cash). The result that PIN fees discourage debit card use altogether raises a few possibilities: The difference between PIN and signature debit is too subtle a distinction for some consumers to recognize; some consumers are constrained by merchant acceptance of PIN debit only; or some consumers would rather not use debit at all if they do not have the option of using a PIN.

Note that the frequency of debit card use appears unaffected by either the presence or the level of the fee (columns 4 and 5 in table 8).

\subsection{Implications for the Effects of Fees on the U.S. Payment System}

The response to the presence of debit card fees has implications for payment method pricing more generally. Consistent with Amromin et al.'s (2005) finding of a strong response to doubling cashpaid highway tolls, the consumer response to PIN debit fees estimated here suggests that any

\footnotetext{
${ }^{23}$ Although we believe most household reports of signature debit fees to be erroneous (as fewer than 1 percent of banks report a signature fee), we take the conservative approach of restricting our PIN fee dummy variable to take on a value of 1 only if the respondent reports a PIN fee.
} 
differential in the price of payment methods at the point of sale could have a considerable effect on payment choice. While the bank-levied PIN fee applies only to PIN-based debit transactions and is made known to cardholders only through fee disclosure mailings - or after the fact on bank statements - merchant-levied surcharges presumably would be posted clearly at the point of sale, potentially eliciting a stronger response 24 Thus, our estimate represents a lower bound of consumer response to payment method pricing.

Changes in the merchant payment mix resulting from fees could affect merchant cost, card issuer cost and revenue, and payment card network traffic, and could also impact automated clearing house $(\mathrm{ACH})$ volumes, check clearing volumes, and the demand for cash. More specifically, the findings on bank fees have implications for merchant "surcharging" for certain payment instruments. Payment card network operating rules (and some state laws) typically place restrictions on the degree to which merchants are permitted to differentially price by payment method 25 These rules often explicitly prohibit merchants from charging consumers extra for credit or debit card transactions. These "no-surcharge rules" have been contested by some merchants, and complaints about them have been incorporated into some of the recent merchant-led lawsuits. And although some merchants may be reluctant to surcharge (if permitted) for fear of losing customer business, some may not: ${ }^{26}$ Our results suggest that the consumer response to a merchant surcharge would be strong, even for surcharges that are small relative to the total purchase amount.

The strength of consumer response to fees is highly relevant for optimality in the theoretical literature on network effects in two-sided markets 27 Specifically, a strong consumer response to fees charged could result in underuse of an electronic card-based system. Underuse would occur for a particular payment instrument if consumers' marginal private net benefit of using the method were less than the marginal social net benefit. The primary concern is that consumers already do

\footnotetext{
${ }^{24}$ In fact, 28.5 percent of debit cardholders in our survey reported that they were unaware of their bank's policy on debit card fees; we recorded these consumers as facing no fee.

${ }^{25}$ Federal law prohibits card associations from prohibiting cash discounts; some state statutes mirror this law. Ten states explicitly forbid surcharging of credit card payments, with certain exceptions.

${ }^{26}$ In 2003, the Reserve Bank of Australia (RBA) prohibited the no-surcharge rule in the Australian credit card market; the initial evidence suggests that relatively few merchants choose to surcharge (see Chang, Evans and Garcia Swartz (2005), p. 341). However, because the RBA simultaneously lowered interchange fees, the incentive for merchants to surcharge has fallen as well.

${ }^{27}$ See, for example, Rochet and Tirole (2002), Gans and King (2003), Schwartz and Vincent (2003), Wright (2002), and Chakravorti and To (1999).
} 
not perceive the external benefit that consumer card use confers to the payment system as a whole; raising the marginal private cost would provide a disincentive to use the card.

\section{Conclusion}

This paper uses the first nationally representative survey on payment use at the point of sale to investigate consumers' use of debit cards. Our rich set of demographics allows us to document usage patterns by consumer characteristics and financial conditions. Our information on bank-assessed fees on debit card use let us evaluate consumer price response for payment methods. Further, our coding of open-ended questions on reasons underlying payment choice lets us parse out both substitution patterns across payment methods as well as the drivers in consumer utility that give rise to consumer preferences across payment methods. Finally, our questions on fees charged by banks for certain types of debit card transactions allow us to evaluate consumer price sensitivity to debit card fees at the point of sale.

As expected, we find that debit cards serve as a substitute primarily for cash and checks. The probability of using debit cards is decreasing with age and increasing with education, and women use debit cards at a higher rate than men. Convenience is cited overwhelmingly as a main reason for using debit cards. The frequency of debit card use is lower for older respondents and higher for households with children.

In addition, consumers respond negatively to fees charged for debit card transactions. The fee charged by banks for PIN-based debit transactions does appear to steer consumers away from PIN debit and toward signature debit. In addition, this fee also appears to dissuade consumers from using debit cards at all: A fee that comprises less than 2 percent of the average purchase amount is associated with a 12 percent reduction in the likelihood of using the card. Because this fee is

charged after the transaction rather than at the point of sale, we view this price response as a lower bound on the consumer response to payment method surcharges.

For only a small set of consumers (about 6 percent of debit card holders) is debit used as a method of behavioral restraint. However, consumer use of debit varies with household financial 
conditions and expectations about the future: Respondents are more likely to use debit cards if they have negative expectations about their future financial condition, and are more likely to use credit cards rather than debit cards if their financial situation has worsened recently. Thus, consumers appear to have an underlying preference for spending from liquidity, and use credit as a source of liquidity during periods of financial stress.

Several questions remain open as areas for future research. First, why has debit rather than credit taken the bulk of business away from checks and cash (even for higher-income, non-creditrevolving households)? For the overwhelming share of debit card users who report that debit is more 'convenient' than other payment methods, what does 'convenience' mean specifically? What is the saturation point for debit card use - is there a base level of cash and check use that will remain even after debit cards have diffused fully into the economy? Answers to these questions and others will help us to understand more fully the complex problem of payment choice. 
Figure 1: Frequency of debit card use among card users

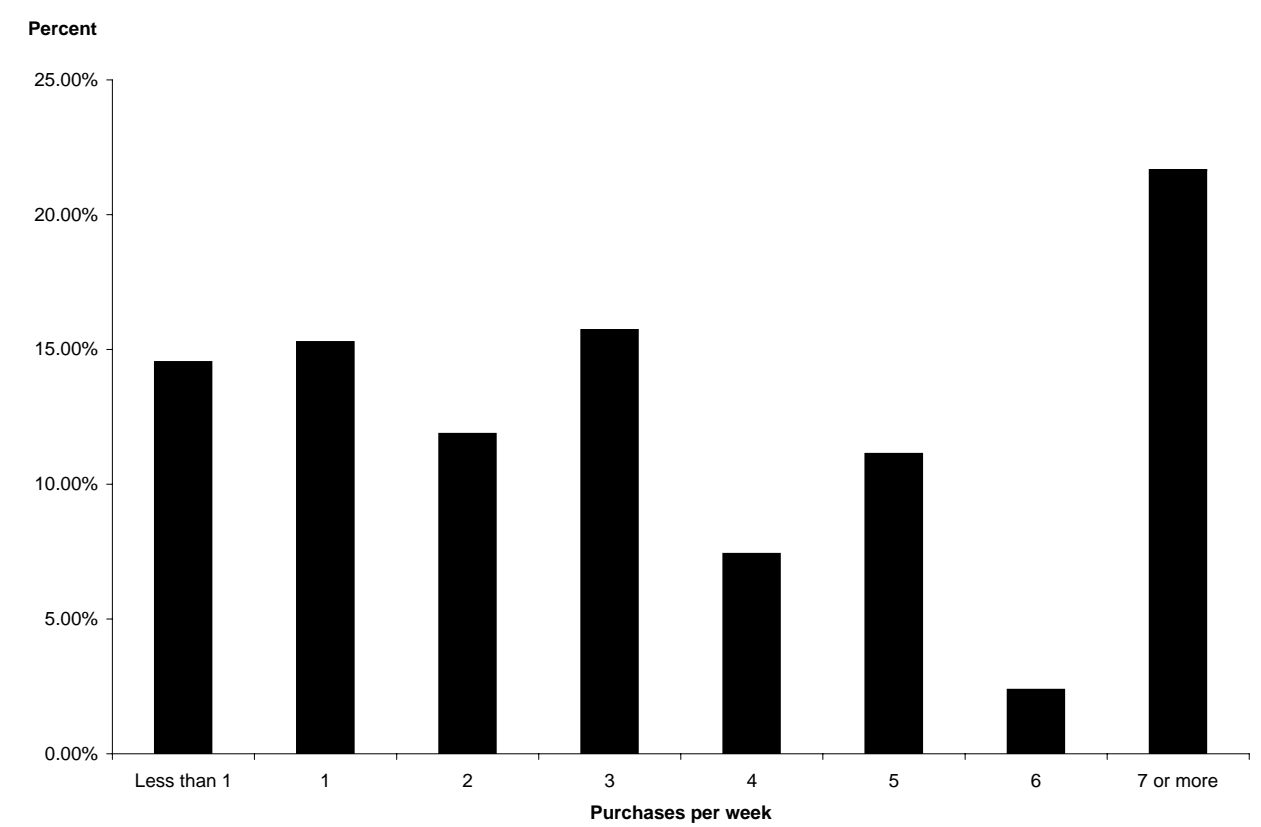


Table 1: Sample composition

\begin{tabular}{lcc}
\hline & Number & Percent of Sample \\
\hline & & \\
Total Interviewed & 1501 & 100.0 \\
Checking Account Holders & 1316 & 87.67 \\
Debit Card Holders & 783 & 52.17 \\
Debit Card Users & 674 & 44.90 \\
\hline \hline
\end{tabular}


Table 2: Demographics of debit card use Percent of Sample

\begin{tabular}{|c|c|c|}
\hline Demographic Characteristic & $\begin{array}{c}\text { Debit Card Holders } \\
(N=783)\end{array}$ & $\begin{array}{c}\text { Checking Account Holders } \\
(N=1316)\end{array}$ \\
\hline \multicolumn{3}{|l|}{ Education } \\
\hline High school diploma or less & 85.0 & 37.9 \\
\hline Some college & 90.6 & 60.6 \\
\hline College/Bachelors degree & 85.0 & 60.0 \\
\hline Graduate degree & 80.4 & 52.2 \\
\hline \multicolumn{3}{|l|}{ Household Income } \\
\hline Less than $\$ 35,000$ & 87.6 & 45.5 \\
\hline$\$ 35,000-\$ 59,999$ & 88.9 & 55.3 \\
\hline$\$ 60,000-\$ 99,999$ & 82.5 & 56.9 \\
\hline$\$ 100,000$ or more & 86.9 & 54.7 \\
\hline \multicolumn{3}{|l|}{ Home Ownership } \\
\hline Owns home & 85.0 & 49.2 \\
\hline Does not own home & 89.9 & 60.2 \\
\hline \multicolumn{3}{|l|}{ Business Phone } \\
\hline Business phone in household & 79.3 & 52.4 \\
\hline No business phone & 86.9 & 51.1 \\
\hline \multicolumn{3}{|l|}{ Age } \\
\hline $18-24$ & 93.9 & 77.5 \\
\hline $25-34$ & 92.8 & 78.3 \\
\hline $35-44$ & 87.8 & 63.5 \\
\hline $45-54$ & 87.5 & 52.7 \\
\hline $55-64$ & 79.3 & 41.4 \\
\hline 65 or older & 69.6 & 20.5 \\
\hline \multicolumn{3}{|l|}{ Sex } \\
\hline Male & 80.9 & 47.1 \\
\hline Female & 90.4 & 54.8 \\
\hline \multicolumn{3}{|l|}{ Race } \\
\hline White except Hispanic & 85.7 & 48.9 \\
\hline Black except Hispanic & 91.8 & 64.4 \\
\hline Hispanic & 91.7 & 65.7 \\
\hline Other & 71.9 & 54.8 \\
\hline \multicolumn{3}{|l|}{ Marital Status } \\
\hline Married & 84.2 & 48.9 \\
\hline Single & 88.6 & 54.5 \\
\hline \multicolumn{3}{|l|}{ Children } \\
\hline One or more children & 88.6 & 61.9 \\
\hline No children & 84.5 & 45.8 \\
\hline All Respondents & 86.1 & 51.2 \\
\hline
\end{tabular}


Table 3: Debit cards vs. other payment methods: Substitution

\begin{tabular}{|c|c|c|}
\hline Substitute * & $\begin{array}{l}\text { Percent Who Use } \\
\text { Debit Instead Of: } \\
\quad(\text { Users }=674)\end{array}$ & $\begin{array}{c}\text { Percent Who, Instead } \\
\text { of Debit, Use: } \\
\text { (Non-Users=109) }\end{array}$ \\
\hline Cash & 48.5 & 22.9 \\
\hline Check & 31.9 & 31.2 \\
\hline Credit & 19.4 & 55.1 \\
\hline Indeterminate & 21.4 & 22.9 \\
\hline
\end{tabular}

* Categories not mutually exclusive. 
Table 4: Payment choice drivers

\begin{tabular}{lcc} 
Utility Characteristic ${ }^{*}$ & $\begin{array}{r}\text { Reasons for Debit } \begin{array}{c}\text { Use } \\
\text { (Users }=674)\end{array} \\
\text { Time }\end{array}$ & $\begin{array}{c}\text { Reasons for No Debit Use } \\
(\text { Non-Users=109) }\end{array}$ \\
Convenience & 14.1 & 5.5 \\
Money & 88.1 & 8.3 \\
Restraint & 11.7 & 21.1 \\
Tracking & 5.8 & 5.5 \\
Acceptance & 10.2 & 40.4 \\
Other & 4.9 & 0.0 \\
\hline \hline
\end{tabular}

* Categories not mutually exclusive. 
Table 5: Substitution behavior and payment drivers for debit card use

\begin{tabular}{|c|c|c|c|c|c|}
\hline Utility Characteristic (N) & Cash & Credit & Check & Indeterminate ${ }^{*}$ & All \\
\hline $\begin{array}{r}\text { Time } \\
(95)\end{array}$ & 50.5 & 23.2 & 44.2 & 19.0 & 14.1 \\
\hline $\begin{array}{l}\text { Convenience } \\
\text { (595) }\end{array}$ & 51.9 & 15.8 & 33.2 & 21.4 & 88.1 \\
\hline $\begin{array}{l}\text { Money } \\
(76)\end{array}$ & 40.5 & 31.7 & 51.9 & 3.8 & 11.7 \\
\hline $\begin{array}{l}\text { Restraint } \\
\text { (39) }\end{array}$ & 48.7 & 69.2 & 23.1 & 2.6 & 5.8 \\
\hline $\begin{array}{l}\text { Tracking } \\
\text { (69) }\end{array}$ & 42.0 & 33.3 & 42.0 & 15.9 & 10.2 \\
\hline $\begin{array}{l}\text { Acceptance } \\
\text { (33) }\end{array}$ & 21.2 & 60.6 & 36.4 & 12.1 & 4.9 \\
\hline $\begin{array}{l}\text { Other } \\
\text { (20) }\end{array}$ & 35.0 & 15.0 & 10.0 & 45.0 & 3.0 \\
\hline $\begin{array}{l}\text { All } \\
(674) \\
\end{array}$ & 48.5 & 31.9 & 19.4 & 21.4 & \\
\hline
\end{tabular}

* Categories not mutually exclusive. 
Table 6: Probits: Predict Holding, Use and Frequency of Debit Cards

\begin{tabular}{|c|c|c|c|c|}
\hline $\begin{array}{l}\text { Demographic } \\
\text { Characteristic } \\
\end{array}$ & Holds a Card & Uses Debit & Uses Debit & $\begin{array}{l}\text { Ordered Probit: } \\
\text { Frequency of Use }\end{array}$ \\
\hline Midwest & $\begin{array}{c}-.477^{* * *} \\
(.123)\end{array}$ & $\begin{array}{c}-.539^{* * *} \\
(.120)\end{array}$ & $\begin{array}{c}-.496^{* *} \\
(.193)\end{array}$ & $\begin{array}{l}-.150 \\
(.122)\end{array}$ \\
\hline Northeast & $\begin{array}{c}-.318^{* *} \\
(.129)\end{array}$ & $\begin{array}{c}-.420^{* * *} \\
(.125)\end{array}$ & $\begin{array}{c}-.503^{* * *} \\
(.194)\end{array}$ & $\begin{array}{c}-.304^{* *} \\
(.130)\end{array}$ \\
\hline South & $\begin{array}{c}-.361^{* * *} \\
(.116)\end{array}$ & $\begin{array}{c}-.360^{* * *} \\
(.113)\end{array}$ & $\begin{array}{l}-.234 \\
(.182)\end{array}$ & $\begin{array}{l}-.108 \\
(.112)\end{array}$ \\
\hline $25-34$ yrs & $\begin{array}{l}.007 \\
(.223)\end{array}$ & $\begin{array}{l}-.003 \\
(.211)\end{array}$ & $\begin{array}{l}-.020 \\
(.329)\end{array}$ & $\begin{array}{l}.090 \\
(.174)\end{array}$ \\
\hline $35-44$ yrs & $\begin{array}{c}-.362^{*} \\
(.213)\end{array}$ & $\begin{array}{c}-.393^{*} \\
(.203)\end{array}$ & $\begin{array}{l}-.312 \\
(.313)\end{array}$ & $\begin{array}{l}-.147 \\
(.181)\end{array}$ \\
\hline $45-54$ yrs & $\begin{array}{c}-.742^{* * *} \\
(.210)\end{array}$ & $\begin{array}{c}-.709^{* * *} \\
(.202)\end{array}$ & $\begin{array}{l}-.359 \\
(.318)\end{array}$ & $\begin{array}{l}-.251 \\
(.188)\end{array}$ \\
\hline $55-64$ yrs & $\begin{array}{c}-.972^{* * *} \\
(.218)\end{array}$ & $\begin{array}{c}-.994^{* * *} \\
(.210)\end{array}$ & $\begin{array}{c}-.643^{* *} \\
(.327)\end{array}$ & $\begin{array}{c}-.388^{*} \\
(.199)\end{array}$ \\
\hline 65 and older & $\begin{array}{c}-1.356^{* * *} \\
(.215)\end{array}$ & $\begin{array}{c}-1.480^{* * *} \\
(.209)\end{array}$ & $\begin{array}{c}-1.007^{* * *} \\
(.333)\end{array}$ & $\begin{array}{c}-.883^{* * *} \\
(.222)\end{array}$ \\
\hline$\$ 35,000-\$ 59,000$ & $\begin{array}{l}.074 \\
(.120)\end{array}$ & $\begin{array}{l}.096 \\
(.119)\end{array}$ & $\begin{array}{l}.137 \\
(.202)\end{array}$ & $\begin{array}{l}.092 \\
(.128)\end{array}$ \\
\hline$\$ 60,000-\$ 99,999$ & $\begin{array}{l}.201 \\
(.127)\end{array}$ & $\begin{array}{l}.103 \\
(.126)\end{array}$ & $\begin{array}{l}-.140 \\
(.201)\end{array}$ & $\begin{array}{l}.197 \\
(.136)\end{array}$ \\
\hline$\$ 100,000$ or more & $\begin{array}{l}.042 \\
(.143)\end{array}$ & $\begin{array}{l}.107 \\
(.142)\end{array}$ & $\begin{array}{l}.161 \\
(.234)\end{array}$ & $\begin{array}{l}.300^{*} \\
(.154)\end{array}$ \\
\hline Female & $\begin{array}{l}.080 \\
(.080)\end{array}$ & $\begin{array}{c}.207^{* * *} \\
(.079)\end{array}$ & $\begin{array}{c}.394^{* * *} \\
(.127)\end{array}$ & $\begin{array}{l}.058 \\
(.085)\end{array}$ \\
\hline Single & $\begin{array}{l}.038 \\
(.114)\end{array}$ & $\begin{array}{l}.078 \\
(.113)\end{array}$ & $\begin{array}{l}.040 \\
(.177)\end{array}$ & $\begin{array}{l}.021 \\
(.122)\end{array}$ \\
\hline Divorced & $\begin{array}{l}.225^{*} \\
(.119)\end{array}$ & $\begin{array}{l}.243^{* *} \\
(.117)\end{array}$ & $\begin{array}{l}.157 \\
(.195)\end{array}$ & $\begin{array}{l}-.022 \\
(.126)\end{array}$ \\
\hline Has one or more children & $\begin{array}{l}-.071 \\
(.098)\end{array}$ & $\begin{array}{l}-.043 \\
(.096)\end{array}$ & $\begin{array}{l}.064 \\
(.151)\end{array}$ & $\begin{array}{l}.188^{*} \\
(.097)\end{array}$ \\
\hline Some college & $\begin{array}{c}.317^{* * *} \\
(.102)\end{array}$ & $\begin{array}{c}.337^{* * *} \\
(.101)\end{array}$ & $\begin{array}{l}.220 \\
(.171)\end{array}$ & $\begin{array}{l}.130 \\
(.111)\end{array}$ \\
\hline Bachelors degree & $\begin{array}{c}.334^{* * *} \\
(.114)\end{array}$ & $\begin{array}{l}.260^{* *} \\
(.113)\end{array}$ & $\begin{array}{l}-.054 \\
(.179)\end{array}$ & $\begin{array}{l}.094 \\
(.122)\end{array}$ \\
\hline Graduate degree & $\begin{array}{c}.347^{* * *} \\
(.128)\end{array}$ & $\begin{array}{l}.184 \\
(.127)\end{array}$ & $\begin{array}{l}-.222 \\
(.191)\end{array}$ & $\begin{array}{l}-.028 \\
(.142)\end{array}$ \\
\hline Non-white & $\begin{array}{l}.233^{* *} \\
(.115)\end{array}$ & $\begin{array}{l}.169 \\
(.109)\end{array}$ & $\begin{array}{l}-.019 \\
(.165)\end{array}$ & $\begin{array}{l}-.073 \\
(.107)\end{array}$ \\
\hline Owns home & $\begin{array}{l}-.034 \\
(.115)\end{array}$ & $\begin{array}{l}-.031 \\
(.113)\end{array}$ & $\begin{array}{l}-.016 \\
(.179)\end{array}$ & $\begin{array}{l}.008 \\
(.118)\end{array}$ \\
\hline Business phone in household & $\begin{array}{l}.094 \\
(.135)\end{array}$ & $\begin{array}{l}-.092 \\
(.131)\end{array}$ & $\begin{array}{c}-.352^{*} \\
(.185)\end{array}$ & $\begin{array}{l}.055 \\
(.144)\end{array}$ \\
\hline Const. & $\begin{array}{c}.926^{* * *} \\
(.268)\end{array}$ & $\begin{array}{c}.715^{* * *} \\
(.257)\end{array}$ & $\begin{array}{c}1.592^{* * *} \\
(.395)\end{array}$ & \\
\hline Obs. & 1205 & 1205 & 743 & 640 \\
\hline Sub-sample & Chk Acct Holders & Chk Acct Holders & DC Holders & DC Users \\
\hline
\end{tabular}

${ }^{* * *}$ Significant at $1 \%$ level. $* *$ Significant at $5 \%$ level. $*$ Significant at $10 \%$ level. 
Table 7: Probits: Predict Debit Use with Financial Indicators

\begin{tabular}{|c|c|}
\hline Characteristic & $\begin{array}{c}\text { Probit: Predicts Debit Use for } \\
\text { Credit Substituters }\end{array}$ \\
\hline Midwest & $\begin{array}{c}-.923^{* *} \\
(.383)\end{array}$ \\
\hline Northeast & $\begin{array}{c}-.740^{* *} \\
(.374)\end{array}$ \\
\hline South & $\begin{array}{c}.138 \\
(.349)\end{array}$ \\
\hline $25-34$ yrs & $\begin{array}{l}-.609 \\
(.906)\end{array}$ \\
\hline $35-44$ yrs & $\begin{array}{r}-1.075 \\
(.873)\end{array}$ \\
\hline $45-54$ yrs & $\begin{array}{c}-1.198 \\
(.890)\end{array}$ \\
\hline $55-64$ yrs & $\begin{array}{r}-1.671^{*} \\
(.918)\end{array}$ \\
\hline 65 and older & $\begin{array}{l}-2.571^{* * *} \\
\quad(.960)\end{array}$ \\
\hline$\$ 35,000-\$ 59,000$ & $\begin{array}{c}-.945^{* *} \\
(.467)\end{array}$ \\
\hline$\$ 60,000-\$ 99,999$ & $\begin{array}{c}-1.145^{* *} \\
(.451)\end{array}$ \\
\hline$\$ 100,000$ or more & $\begin{array}{l}-.798 \\
(.517)\end{array}$ \\
\hline Female & $\begin{array}{c}1.027^{* * *} \\
(.298)\end{array}$ \\
\hline Single & $\begin{array}{l}-.121 \\
(.381)\end{array}$ \\
\hline Divorced & $\begin{array}{l}.561 \\
(.544)\end{array}$ \\
\hline Has one or more children & $\begin{array}{l}-.054 \\
(.357)\end{array}$ \\
\hline Some college & $\begin{array}{c}.277 \\
(.444)\end{array}$ \\
\hline Bachelors degree & $\begin{array}{l}.276 \\
(.429)\end{array}$ \\
\hline Graduate degree & $\begin{array}{c}.072 \\
(.431)\end{array}$ \\
\hline
\end{tabular}

continued on next page 
Table 7: continued

Probit: Predicts Debit Use for

\begin{tabular}{lc} 
Characteristic & Credit Substituters \\
\hline Non-white & -.055 \\
& $(.354)$ \\
Owns home & .119 \\
& $(.403)$ \\
Business phone in household & -.585 \\
& $(.393)$ \\
Financial situation better now & .250 \\
& $(.348)$ \\
Financial situation worse now & $-.678^{*}$ \\
& $(.397)$ \\
Financial situation will be better in a year & -.547 \\
Financial situation will be worse in a year & $(.339)$ \\
& $1.010^{*}$ \\
Income will increase in next 12 mos. & $(.530)$ \\
Income will decrease in next 12 mos. & -.037 \\
50-100\% chance of losing job $50 \%$ chance of losing job & $(.413)$ \\
& -.706 \\
Obs. & $(.514)$ \\
\hline
\end{tabular}


Table 8: Probits: Effects of Fees on Debit Card Use and Frequency

\begin{tabular}{|c|c|c|c|c|c|}
\hline Demographic Characteristic & Use Debit & Use Debit & $\begin{array}{c}\text { Use Signature } \\
\text { Only }\end{array}$ & $\begin{array}{l}\text { Ordered Probit: } \\
\text { Freq. of Use }\end{array}$ & $\begin{array}{l}\text { Ordered Probit. } \\
\text { Freq. of Use }\end{array}$ \\
\hline Midwest & $\begin{array}{c}-.454^{* *} \\
(.194)\end{array}$ & $\begin{array}{c}-.468^{* *} \\
(.194)\end{array}$ & $\begin{array}{l}.421^{* *} \\
(.178)\end{array}$ & $\begin{array}{l}-.146 \\
(.122)\end{array}$ & $\begin{array}{l}-.146 \\
(.122)\end{array}$ \\
\hline Northeast & $\begin{array}{c}-.471^{* *} \\
(.195)\end{array}$ & $\begin{array}{c}-.476^{* *} \\
(.195)\end{array}$ & $\begin{array}{l}-.045 \\
(.200)\end{array}$ & $\begin{array}{c}-.303^{* *} \\
(.130)\end{array}$ & $\begin{array}{c}-.303^{* *} \\
(.130)\end{array}$ \\
\hline South & $\begin{array}{l}-.207 \\
(.183)\end{array}$ & $\begin{array}{l}-.202 \\
(.184)\end{array}$ & $\begin{array}{l}.210 \\
(.169)\end{array}$ & $\begin{array}{l}-.108 \\
(.112)\end{array}$ & $\begin{array}{l}-.100 \\
(.112)\end{array}$ \\
\hline $25-34$ yrs & $\begin{array}{l}-.041 \\
(.331)\end{array}$ & $\begin{array}{l}-.043 \\
(.333)\end{array}$ & $\begin{array}{l}-.140 \\
(.265)\end{array}$ & $\begin{array}{l}.086 \\
(.174)\end{array}$ & $\begin{array}{l}.086 \\
(.174)\end{array}$ \\
\hline $35-44$ yrs & $\begin{array}{l}-.357 \\
(.315)\end{array}$ & $\begin{array}{l}-.373 \\
(.318)\end{array}$ & $\begin{array}{l}.249 \\
(.268)\end{array}$ & $\begin{array}{l}-.152 \\
(.181)\end{array}$ & $\begin{array}{l}-.157 \\
(.181)\end{array}$ \\
\hline $45-54$ yrs & $\begin{array}{l}-.409 \\
(.321)\end{array}$ & $\begin{array}{l}-.420 \\
(.324)\end{array}$ & $\begin{array}{l}-.066 \\
(.284)\end{array}$ & $\begin{array}{l}-.258 \\
(.188)\end{array}$ & $\begin{array}{l}-.264 \\
(.188)\end{array}$ \\
\hline $55-64$ yrs & $\begin{array}{c}-.710^{* *} \\
(.331)\end{array}$ & $\begin{array}{c}-.720^{* *} \\
(.334)\end{array}$ & $\begin{array}{l}.044 \\
(.301)\end{array}$ & $\begin{array}{c}-.400^{* *} \\
(.200)\end{array}$ & $\begin{array}{c}-.406^{* *} \\
(.200)\end{array}$ \\
\hline 65 and older & $\begin{array}{c}-1.060^{* * *} \\
(.336)\end{array}$ & $\begin{array}{c}-1.093^{* * *} \\
(.339)\end{array}$ & $\begin{array}{l}.109 \\
(.321)\end{array}$ & $\begin{array}{c}-.896^{* * *} \\
(.222)\end{array}$ & $\begin{array}{c}-.906^{* * *} \\
(.223)\end{array}$ \\
\hline$\$ 35,000-\$ 59,000$ & $\begin{array}{l}.134 \\
(.202)\end{array}$ & $\begin{array}{l}.135 \\
(.202)\end{array}$ & $\begin{array}{l}.134 \\
(.183)\end{array}$ & $\begin{array}{l}.093 \\
(.128)\end{array}$ & $\begin{array}{l}.091 \\
(.128)\end{array}$ \\
\hline$\$ 60,000-\$ 99,999$ & $\begin{array}{l}-.146 \\
(.201)\end{array}$ & $\begin{array}{l}-.141 \\
(.202)\end{array}$ & $\begin{array}{l}-.292 \\
(.205)\end{array}$ & $\begin{array}{l}.191 \\
(.137)\end{array}$ & $\begin{array}{l}.184 \\
(.137)\end{array}$ \\
\hline$\$ 100,000$ or more & $\begin{array}{l}.147 \\
(.234)\end{array}$ & $\begin{array}{l}.143 \\
(.235)\end{array}$ & $\begin{array}{l}.008 \\
(.220)\end{array}$ & $\begin{array}{l}.298^{*} \\
(.154)\end{array}$ & $\begin{array}{l}.291^{*} \\
(.154)\end{array}$ \\
\hline Female & $\begin{array}{c}.401^{* * *} \\
(.127)\end{array}$ & $\begin{array}{c}.416^{* * *} \\
(.128)\end{array}$ & $\begin{array}{l}-.102 \\
(.122)\end{array}$ & $\begin{array}{l}.058 \\
(.085)\end{array}$ & $\begin{array}{l}.060 \\
(.085)\end{array}$ \\
\hline Single & $\begin{array}{l}.023 \\
(.178)\end{array}$ & $\begin{array}{l}.031 \\
(.178)\end{array}$ & $\begin{array}{l}-.072 \\
(.183)\end{array}$ & $\begin{array}{l}.018 \\
(.122)\end{array}$ & $\begin{array}{l}.020 \\
(.122)\end{array}$ \\
\hline Divorced & $\begin{array}{l}.158 \\
(.196)\end{array}$ & $\begin{array}{l}.143 \\
(.196)\end{array}$ & $\begin{array}{l}-.049 \\
(.182)\end{array}$ & $\begin{array}{l}-.026 \\
(.126)\end{array}$ & $\begin{array}{l}-.032 \\
(.126)\end{array}$ \\
\hline Has one or more children & $\begin{array}{l}.067 \\
(.152)\end{array}$ & $\begin{array}{l}.078 \\
(.152)\end{array}$ & $\begin{array}{l}-.006 \\
(.142)\end{array}$ & $\begin{array}{l}.187^{*} \\
(.097)\end{array}$ & $\begin{array}{l}.189^{*} \\
(.097)\end{array}$ \\
\hline Some college & $\begin{array}{l}.241 \\
(.172)\end{array}$ & $\begin{array}{l}.206 \\
(.172)\end{array}$ & $\begin{array}{l}.010 \\
(.162)\end{array}$ & $\begin{array}{l}.131 \\
(.111)\end{array}$ & $\begin{array}{l}.123 \\
(.111)\end{array}$ \\
\hline Bachelors degree & $\begin{array}{l}-.070 \\
(.179)\end{array}$ & $\begin{array}{l}-.075 \\
(.180)\end{array}$ & $\begin{array}{l}-.063 \\
(.179)\end{array}$ & $\begin{array}{l}.092 \\
(.122)\end{array}$ & $\begin{array}{l}.088 \\
(.122)\end{array}$ \\
\hline Graduate degree & $\begin{array}{l}-.240 \\
(.192)\end{array}$ & $\begin{array}{l}-.246 \\
(.192)\end{array}$ & $\begin{array}{l}.168 \\
(.200)\end{array}$ & $\begin{array}{l}-.033 \\
(.142)\end{array}$ & $\begin{array}{l}-.034 \\
(.142)\end{array}$ \\
\hline Non-white & $\begin{array}{l}-.004 \\
(.166)\end{array}$ & $\begin{array}{l}-.021 \\
(.166)\end{array}$ & $\begin{array}{c}-.378^{* *} \\
(.173)\end{array}$ & $\begin{array}{l}-.068 \\
(.107)\end{array}$ & $\begin{array}{l}-.071 \\
(.107)\end{array}$ \\
\hline Owns home & $\begin{array}{l}-.020 \\
(.180)\end{array}$ & $\begin{array}{l}-.045 \\
(.181)\end{array}$ & $\begin{array}{l}.175 \\
(.177)\end{array}$ & $\begin{array}{l}.010 \\
(.118)\end{array}$ & $\begin{array}{l}.006 \\
(.118)\end{array}$ \\
\hline Business phone in household & $\begin{array}{l}-.293 \\
(.190)\end{array}$ & $\begin{array}{l}-.294 \\
(.189)\end{array}$ & $\begin{array}{l}.118 \\
(.208)\end{array}$ & $\begin{array}{l}.058 \\
(.144)\end{array}$ & $\begin{array}{l}.063 \\
(.144)\end{array}$ \\
\hline Bank charges fee with PIN use & & & $\begin{array}{l}.451^{* *} \\
(.194)\end{array}$ & & \\
\hline Bank charges fee & $\begin{array}{c}-.458^{* *} \\
(.184)\end{array}$ & & & $\begin{array}{l}-.095 \\
(.138)\end{array}$ & \\
\hline Fee level & & $\begin{array}{c}-.301^{* *} \\
(.120)\end{array}$ & & & $\begin{array}{l}-.107 \\
(.096)\end{array}$ \\
\hline Const. & $\begin{array}{c}1.668^{* * *} \\
(.399)\end{array}$ & $\begin{array}{c}1.690^{* * *} \\
(.401)\end{array}$ & $\begin{array}{c}-1.129^{* * *} \\
(.374)\end{array}$ & & \\
\hline Obs. & 743 & 743 & 640 & 640 & 640 \\
\hline
\end{tabular}

***Significant at $1 \%$ level. ** Significant at $35 \%$ level. * Significant at $10 \%$ level. 


\section{References}

Amromin, Gene, Carrie Jankowski, and Richard D. Porter, "Transforming Payment Choices by Doubling Fees on the Illinois Tollway," 2005. Federal Reserve Bank of Chicago working paper.

ATM and Debit News, "EFT Data Book," September 15, 2005, 5 (44).

Borzekowski, Ron and Elizabeth K. Kiser, "Network Effects and the Diffusion of Debit Card Use at the Point of Sale," September 2005. Working paper, Federal Reserve Board.

_ and __ "The Choice at the Checkout: Competition Among Payment Instruments," April 2006. FEDS Working Paper no. 2006-17, Federal Reserve Board.

Carow, Kenneth A. and Michael E. Staten, "Debit, Credit, and Cash: Survey Evidence on Gasoline Purchases," Journal of Economics and Business, 1999, 51 (5), 409-422.

Chakravorti, Sujit and Ted To, "A Theory of Credit Cards," November 1999. Working paper No. 99-16, Federal Reserve Bank of Chicago.

Chang, Howard, David S. Evans, and Daniel D. Garcia Swartz, "The Effect of Regulatory Intervention in Two-Sided Markets: An Assessment of Interchange-Fee Capping in Australia," Review of Network Economics, 2005, 4 (December), 328-358.

Dove Consulting and the American Bankers Association, "Study of Consumer Payment Preferences 2004/2005," December 2005.

Federal Reserve Board, "Report to the Congress on the Disclosure of Point-of-Sale Debit Fees," January 252004.

Gans, Joshua and Stephen King, "The Neutrality of Interchange Fees in Payment Systems," Topics in Economic Analysis and Policy, 2003, 3 (1).

Gerdes, Geoffrey R., Jack K. Walton II, May X. Liu, and Darrel W. Parke, "Trends in the Use of Payment Instruments in the United States," Federal Reserve Bulletin, 2005, Spring, $180-201$.

Gross, David B. and Nicholas S. Souleles, "Do Liquidity Constraints and Interest Rates Matter for Consumer Behavior? Evidenc from Credit Card Data," Quarterly Journal of Economics, 2002, 117, 149-185.

Hancock, Diana and David B. Humphrey, "Payment Transactions, Instruments, and Systems: A Survey," Journal of Banking and Finance, 1998, 21 (11-12). 
Hayashi, Fumiko and Elizabeth Klee, "Technology Adoption and Consumer Payments: Evidence from Survey Data," Review of Network Economics, June 2003, 2 (2), 175-190.

Hirschman, Elizabeth, "Consumer Payment Systems: The Relationship of Attribute Structure to Preference and Usage," Journal of Business, 1982, 55 (4), 531-545.

Humphrey, David B, Moshe Kim, and Bent Vale, "Realizing the Gains from Electronic Payments: Costs, Pricing, and Payment Choice," Journal of Money, Credit and Banking ', May 2001, 33 (2, Part 1), 216-234.

Jonker, Nicole, "Payment Instruments as Perceived by Consumers - a Public Survey," September 2005. Working paper, De Nederlandsche Bank.

Kennickell, Arthur B. and Myron L. Kwast, "Who Uses Electronic Banking? Results from the 1995 Survey of Consumer Finances," July 1997. Prepared for presentation at the Annual Meetings of the Western Economic Association, Seattle, Washington.

Kiser, Elizabeth K., "Household switching behavior at depository institutions: evidence from survey data," The Antitrust Bulletin, 2002, 47 (4), 619-640.

Klee, Elizabeth, "Families' Use of Payment Instruments During a Decade of Change in the U.S. Payment System," November 2005. Working paper, Federal Reserve Board.

Loix, Ellen, Roland Pepermans, and Leo Van Hove, "Who's Afraid of the Cashless Society? Belgian Survey Evidence," October 2005. Working paper, Free University of Brussels.

Mantel, Brian, "Why Do Consumers Pay Bills Electronically? An Empirical Analysis," Economic Perspectives, 2000, (Quarter IV), 32-47.

Prelec, Drazen and George Loewenstein, "The Red and Black: Mental Accounting of Savings and Debt," Marketing Science, 1998, 17 (1), 4-28.

Rochet, Jean-Charles and Jean Tirole, "Cooperation Among Competitors: Some Economics of Payment Card Associations," RAND Journal of Economics, 2002, 33 (4), 459-570.

Rysman, Marc, "Competition Between Networks: A Study of the Market for Yellow Pages," Review of Economic Studies, 2004, 71 (2), 483-512.

Schwartz, Marius and Daniel Vincent, "The No Surcharge Rule and Card User Rebates: Vertical Control by a Payment Network," 2003. working paper.

Stavins, Joanna, "Effect of Consumer Characteristics on the Use of Payment Instruments," New England Economic Review, 2001, (3), 19-31. 
Sullivan, James X., "Borrowing During Unemployment: Unsecured Debt as a Safety Net," 2005. Working paper, University of Notre Dame.

Thaler, Richard, "Mental Accounting and Consumer Choice," Marketing Science, 1985, 4 (3), 199-214.

Wright, Julian, "Optimal Card Payment Systems," European Economics Review, 2002, 47, 587612.

Zinman, Jonathan, "Debit or Credit?," 2005. Working paper, Dartmouth University. 